\title{
MISCELLANEOUS COMMUNICATIONS
}

\section{The Pabhosa Inscriptions}

From a cave-residence at Pabhōsā, close to Kōsam in the Allahābād District, we have two inscriptions which present matter for comment. ${ }^{1}$ They were edited in Epi. Ind., vol. 2, pp. 242, 243, by Dr. Führer, who, on account of the resemblance of their letters to those of the Sunga period, B.C. 183 to 72, assigned them to "the second or first century B.c." And Bühler gave in his Indian Palocography, plate 2, col. 19, an alphabet from them, which on the same basis he assigned to "about B.c. 150." 2

The two inscriptions register one and the same act, the founding of the cave: but they do so in different terms :-

No. 1, which is on the rock outside the cave, over the left corner of the entrance door, says:- "By Āsādhasēna, maternal uncle of the Räjan Gōpāliputra-Bahasatimittra (and) son of Gopāli the Vaihidarì, (this) cave has been caused to be made, in the tenth year of Ūdaka (?), [for the use] of the Kaśsapiya Arahamtas."

No. 2, which is inside the cave, on the west wall, says:- "Caused to be made by Ashādhasēna, son of the Vaihidari, (and) son of the Rājan TèvaniputtraBhāgavata, son of Vangapāla Rājan of Adhichhatrā (and) son of Śōnakāyana."

I They are Nos. 904, 905, in Professor Lüders's List of the Brāhmī Inscriptions, Epi. Ind., vol. 10, appendix.

2 He compared the characters of them with those of the inscription, which refers itself to the time of the Sungas, on a pillar at Bharant, Ind. Ant., vol. 14, p. 138, from which, with two letters, $\bar{u}$ and $l \bar{l}$, added from other sources, he gave an alphabet in col. 18 of the same plate, with the same assignment, "about B.C. 150." 
The purport of these two inscriptions is calculated to present them as being very closely contemporaneous, if not actually so. And Bühler seems to have regarded them in that light: at any rate, he gave a combined alphabet from them, taking his illustrations, indeed, chiefly from No. 1, but figuring at least the $k \bar{\alpha}, \tilde{n} \bar{o}$ (imperfectly), $a h i$, and śo from No. 2. But we must bear in mind that he did not choose by any means all the selections presented in his plates: also, that the magnitude of his task was such as to preclude the detailed examination of records which becomes necessary in other circumstances. And an inspection of details in this case shows marked differences between the two records, which tend to separate them somewhat widely.

First, as regards language. The language of both the records is classed as Mixed Dialect: but that of No. 2 is an advance on that of No. 1, which is more of a Präkrit. It is true that No. 1 has $\operatorname{ra} j \tilde{j} \bar{o}$, once, while No. 2 has rāñ $\bar{o}$, twice. But No. 2 has putrēna, with the lingual n, twice, against the putrenna, with the dental $n$, once, of No. 1 : and it has the genitive in sya, four times, against the genitive in $s a$, twice or perhaps three times, of No. $1{ }^{1}$ In No. 2 the first component of the name of the founder of the cave is ash $\bar{a} d h a$ (for $\bar{a} \operatorname{sh} \bar{a} d h a$ ): in No. 1 it is $\bar{a} s \bar{a} d h a$ (also for $\bar{\alpha} s h \bar{\alpha} d h \alpha$ ).

Secondly, as regards the alphabet: here we have differences between the two records which are not indicated at all by the selection given in Bühler's plate.

No. 1 presents two types of $\dot{r}$. One $r$ is of the same general style with the waved $r$ which is found in the records of Aśōka at Girnār and Rūpnāth and in Mysore ; ${ }^{2}$

1 In No. $1,1.6$, the word $\bar{u} d \bar{a} k a s \alpha$ is damaged and doubtful : but the last syllable of it is at any rate not $8 y a$. The first syllable seems to be the long $\bar{u}$; not the short $u$ as read by Professor Lüders.

2 See Bühler, ii, 34, viii-xii. 
but it is not waved to the same extent, the bends being reduced in number by using longer strokes for them: this $r$ occurs twice, in $r \bar{a} j \tilde{n} \bar{o}, 1.1$, and vaihidar $\bar{\imath}, 1.4$, and has been illustrated by Bühler from the latter word. The other $r$ is of the type in which the waved stroke was superseded by a plain straight one $:^{1}$ this $r$, which was not illustrated, is seen very clearly in käritam, 1. 6, and is also found in savachhare $\bar{e}$ and araham, 1. 7.

No. 2, again, presents two types of $r$, neither of which is illustrated by the selection. It has not the waved $r$; except to the extent to which the subscript $r$ is waved in both this record and in No. 1, in the stage before that in which it assumed the form of a smooth sweeping curved stroke. It has (1) the plain straight $r$ of No. 1, which it

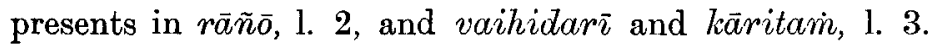
And it has (2) a still later type-later by two stages, in fact-in which the bottom of the letter was finished off by a bend up to the left: this is presented in $r \bar{a} \tilde{n} \bar{o}, 1.1$.

In No. 1 the subscript $u$ in putrasa, 1. 1, and putrêna, 1. 4 , is a plain straight vertical stroke. ${ }^{2}$ In No. 2, in puttrasya at the middle of 1.2 , the $u$ is finished off, to match the second $r$ of this record, by a bend up to the left; and in putrasya at the beginning of 1.2 and putrena at the end of that line and again in 1.3 , either the same form was intended but was not properly completed, or we have instances of an intermediate type, similar to that through which the $r$ passed, in which the letter was finished off by a curve down to the left, before the bend upwards was developed.

I In this $r$ in both the records, and in many other letters too, the straight lines which were intended have not always been well followed : but the intention is plain.

2 In mätulena, 1.3 , the $u$ is of a different type, as was customary in connection with the letter $t$; being a short straight horizontal stroke to the right from the end of the lower right-hand part of the $t$, as in Bühler's ii, 23, v, viii, xxiv. 
There are other letters the development of which also went more or less along with that of the $r^{1}$ One is the palatal $\tilde{n}$. In No. 1 the main stroke of this letter is a plain straight one. In No. 2 it is finished off, as in the $r$, by a bend up to the left: this can be seen clearly in the räñ $\bar{o}$ of 1 . 1, though this $\tilde{n} \bar{o}$ has been figured in the selection without showing this detail; and it seems to have been intended in also the rāño of 1. 2 .

Other such letters are the initial $a$ and $\bar{a}$. Both of these occur in No. 1; and each of them is formed there entirely between what we may call the two lines of the writing. ${ }^{2}$ In No. 2 we have apparently only the short $\alpha$, twice $:^{3}$ in both cases the vertical stroke is prolonged, like that of the $r$, to a length below the bottom line of the writing equal to about the measure between the lines; and in one of them, in adhichhatr $\bar{\alpha} y \bar{\alpha}, 1.1$, though perhaps not in the other case in 1. 3, there seems to have been an intention, not fully carried out, to finish off the vertical, as in the $r$ and $\tilde{n}$ of the next word, $r \bar{a} \tilde{n} \bar{o}$, by a bend up to the left. These details, again, are not shown in the selection in Bühler's plate, where both the vowels are figured from the inscription No. 1.

In view of such differences as these, in both the language and the alphabet, it is plain that the two inscriptions cannot have been either composed by the same person or written by the same hand, at any rate

I The $k$ in particular is such a letter: in these two inscriptions, however, we have only the $k$ which matched the second $r$ of No. l and the first $r$ of No. 2 ; not the $k$, with the bend up to the left at the bottom of the vertical stroke, which answered to the second $r$ of No. 2 .

2 This expression is a convenient way of indicating the limits and size of such letters as were made like our a, c, e, m, etc, without any projections above as in $b, d, f$, or below as in $g, j, p$. But, whatever may have been done in subsequent times, the more ancient writers evidently did not use much, if at all, the expedient of ruling two such lines with a view to insuring uniformity in their work; and the result was generally a considerable variation in the relative sizes of all the letters.

3 In l. 3, ashādha seems to have been written, instead of $\bar{a} s h \bar{a} d h a$. 
not at all at the same time, and cannot be contemporaneous records: an appreciable interval must be placed between them. We need not hesitate to accept Bühler's estimate, about B.c. 150, as the approximate date of No. 1 : it is justified by the general style of the characters, and in particular by the occurrence of the waved $r$ and the form of it which is presented. But No. 2 must be placed at least half a century later; though the use in it, as in No. 1, of a peculiar form of the superscript long $\bar{\imath}$, resembling in some cases the twisted horns of an antelope, ${ }^{1}$ seems to preclude any much longer interval than that. And it seems to be a commemorative record, due to a son, grandson, or relative, or some admirer, of Āshāḍasēna: apparently the inscription No. 1 was not easily readable, if at all, from the ledge in front of the cave, and No. 2 was therefore put up in a convenient position inside the cave, so that the name of the founder of the cave might be known and his memory might be preserved.

J. F. Fleet.

\section{GiNGER}

The short note which I contributed under the above heading to this Journal for 1912 (p. 475 f.) has elicited communications from several scholars which encourage me to ventilate the same subject once more and to sum up the results of its discussion by Dr. Thomas and others.

The late Rai Bahadur V. Venkayya informed me that in Tamil the word verklkombu is used for both green and dry ginger, and that the usual Tamil word for "dry ginger" is sukku. The former fact was mentioned also by Professor Kern, and the second by Mr. P. T. Srinivasa Iyengar. First of all it may be convenient to arrange

${ }^{1}$ Figured by Bühler, along with the waved $r$, in the $r i$ of vaihidari, No. 1, 1. 4. 